\title{
UJI KUALITAS BIOBRIKET CAMPURAN TEMPURUNG KELAPA, TONGKOL JAGUNG, dan SEKAM PADI DENGAN TEPUNG SAGU SEBAGAI PERAKAT
}

\author{
Ahmad Marzuki Muhlis, Sahara, dan Nurul Fuadi ${ }^{1}$ \\ 1Jurusan Fisika, Fakultas Sains dan Teknologi, UIN Alauddin Makassar \\ Email: fisika013@gmail.com, rarafis_uin@yahoo.co.id, \\ nurul.fuadi@uin-alauddin.ac.id
}

\begin{abstract}
Research has been carried out with the title of the biobriquette quality mixture of coconut shell, corn cobs, and rice husk with sago flour as adhesive. The purpose of this study was to determine the quality of the bio-briquettes with a mixture of coconut shells, corn cobs and rice husks with sago flour as an adhesive. In this study the raw material used was coconut shell with the process of drying at temperatures of $350^{\circ} \mathrm{C}$, corn cobs with a temperature of $150^{\circ} \mathrm{C}$ and rice husks with a temperature of $120^{\circ} \mathrm{C}$ with the composition used was 60\%: 20\%: 20\%, 60\%: 25\%: 15\%, 60\%: 30\%: $10 \%$ and $60 \%$ : $35 \%: 5 \%$ then sieving particle size for all 40 mesh samples, mixing using 3 grams of sago flour as bio-briquette adhesive, then bio-briquette printing and drying is done. Furthermore testing of compressive strength, moisture content, ash content, calorific value and combustion time with the results of compressive strength testing using the tool. TA.XTPlus Texture Analyzer the best characteristics obtained in the composition $60 \%$ : $35 \%: 5 \%$ with a value of $9.82 \mathrm{~kg} / \mathrm{cm}^{2}$, and the best characteristic moisture content was tested in the composition of $60 \%$ : $30 \%: 10 \%$ with a value of $4.59 \%$. The quality produced from the biobriquette mixture of coconut shell, corn cobs, and rice husk with sago flour as adhesive can be categorized as good. This is seen from the testing of water content, ash content and calorific value that meets the Indonesian national standard and the burning time of 152.18 minutes, except for compressive strength testing that does not equal to the quality standards of Indonesia.
\end{abstract}

Keywords: bio-briquette, coconut shell, corn cobs, rice husk, sago flour and composition variations.

\section{PENDAHULUAN}

Energi merupakan permasalahan utama dimana kebutuhan akan energi semakin meningkat seiring dengan semakin meningkatnya aktivitas manusia yang menggunakan bahan bakar, khususnya bahan bakar minyak yang dihasilkan dari fosil tumbuhan maupun hewan. Menurut lka Yudita Permatasari dan Budi Utami (2015) dikutip dari Hambali dkk (2007) Indonesia yang semula adalah net-exporter 
BBM telah menjadi net-importer BBM sejak tahun 2000. Padahal cadangan minyak bumi Indonesia hanya sekitar 9 miliar barel dan produksi Indonesia hanya sekitar 500 juta barel per tahun. Ini artinya jika terus dikonsumsi dan tidak ditemukan cadangan untuk meningkatkan recovery minyak bumi, diperkirakan cadangan minyak bumi Indonesia akan habis dalam waktu dua puluh tiga tahun mendatang. Menurut kutipan Kristanto (2013) dalam Ika Yudita Permatasri dan Budi Utami (2015), menyatakan bahwa biomassa merupakan salah satu sumber energi yang paling umum dan mudah diakses yang dapat diolah menjadi bioenergi. Biomassa memiliki jumlah yang melimpah karena dihasilkan dari aktivitas manusia ataupun proses alam dan juga memiliki potensi sumber daya energi yang besar. Potensi energi biomassa 50.000 MW akan tetapi hanya $320 \mathrm{MW}$ atau $0.64 \%$ yang sudah dimanfaatkan. Hal ini menunjukkan bahwa energi biomassa belum dimanfaatkan secara optimal, biasanya hanya dibuang begitu saja dan dibiarkan menumpuk sebagai limbah. Landasan penelitian ini didasar oleh dua hal yakni persediaan dan produksi bahan bakar dunia yang semakin berkurang, yang dapat berdampak pada penggunaan energi beberapa tahun kedepan menjadi krisis, oleh sebab itu diperlukannya bahan bakar altrnatif yaitu briket yang memanfaatkan limbah pertanian sebagaimana yang telah dilakukan oleh Nurdin, 2018 dan hal yang kedua adalah ingin dihasilkan kualitas briket yang lebih baik dari pada sebelumnya. Briket tempurung kelapa yang memiliki nilai kalor yang memenuhi standar, namun terjadi reduksi kualitas jika ditinjau dari kadar airnya. Begitupun dengan briket tongkol jagung dan sekam padi, di beberapa tinjuan belum memenuhi standar yang diinginkan.

Berdasarkan latar belakang diatas, penelitian ini mencoba untuk melakukan kombinasi arang tempurung kelapa, tongkol jagung, dan sekam padi dengan harapan kualitas yang dihasilkan memenuhi standarisasi kualitas briket dengan waktu pembekaran lebih lama. Campuran material tersebut direkatkan dengan menggunakan tepung sagu. Tempurung kelapa adalah salah satu bahan karbon aktif yang kualitas cukup baik dijadikan arang aktif. Struktur keras pada tempurung kelapa disebabkan oleh adanya kakndungan silikat $\left(\mathrm{SiO}_{2}\right)$ yang cukup tinggi kadarnya.

Tongkol jagung merupakan salah satu material yang digunakan untuk menghasilkan sampel biobriket. Unsur dalam tongkol jagung terdiri dari beberapa unsur seperti unsur karbon $43,42 \%$, dan hydrogen $6.32 \%$. Nilai kalor dari tongkol jagung berkisar 14.7-18.9 MJ/kg. Untuk meningkatkan lama pembakaran, sekam padi juga digunakan pada material biobriket. Sekam padi memiliki kerapatan jenis bulk density $125 \mathrm{~kg} / \mathrm{m}^{3}$, nilai kalori $1 \mathrm{~kg}$ sekam padi sebesar 3300 kilokalori. Komposisi kimia yang terdapat pada sekam padi yakni karbon $1.33 \%$, hidrogen $1,54 \%$, oksigen 33,365 , dan silica $16,98 \%$. Bahan yang digunakan untuk menggabungkan material penyusun pada pembuatan biobriket yakni berbahan dasar tepung. Unsur-unsur yang terkadang dari tepung diperlihatkan oleh tabel 1. 
Tabel 1. Kandung komposisi dari berbagai jenis tepung (Mubarok, 2015)

\begin{tabular}{|c|c|c|c|c|c|c|}
\hline Jenis tepung & Air(\%) & $\begin{array}{c}\text { Lemak } \\
(\%)\end{array}$ & $\begin{array}{c}\text { Serat } \\
\text { kasar (\%) }\end{array}$ & $\begin{array}{c}\text { Protein } \\
(\%)\end{array}$ & $\begin{array}{c}\text { Serat } \\
\text { kasar (\%) }\end{array}$ & $\begin{array}{c}\text { Karbon } \\
(\%)\end{array}$ \\
\hline $\begin{array}{c}\text { Tepung } \\
\text { Jagung }\end{array}$ & 10,52 & 4,89 & 1,27 & 8,48 & 1,04 & 738 \\
\hline Tepung Beras & 7,58 & 0,68 & 4,53 & 9,89 & 0,82 & 76,9 \\
\hline $\begin{array}{c}\text { Tepung } \\
\text { Terigu }\end{array}$ & 10,7 & 0,86 & 2 & 11,5 & 0,64 & 74,2 \\
\hline $\begin{array}{c}\text { Tepung } \\
\text { Tapioka }\end{array}$ & 9,86 & 0,36 & 1,5 & 2,21 & 0,69 & 85,2 \\
\hline
\end{tabular}

Menurut Adan (1998) jumlah perekat yang digunakan pada pembuatan briket yakni sebanyak $10 \%$ dari berat arang yang akan digunakan pada pembuatan briket. Perakat organik menghasilkan abu yang relatif sedikit setelah pembakaran briket, dan umumnya merupakan bahan perekat yang efektif. Salah satu perekat yang efektif yakni sagu karena sagu dapat menghasilkan kekuatan rekat kering yang tinggi. Secara kimia, komposisi sagu terdiri dari $28 \%$ amilosa, dan $27 \%$ amilopektin sehingga dapat digunakan sebagai perekat (Brades dan Tobing, 2008). Perekat tersebut digunakan untuk menggabungkan material dasar penyusun briket dimana material penysusun tersebut dapat mempengaruhi kualitas briket.

Kualitas briket yang baik memiliki kandungan karbon yang besar dengan sedikit abu, mudah terbakar, menghasilkan energy panas yang tinggi, dan tahan lama sebagaimana dinyatakan oleh Yusuf, S., 2013. Model briket yang dirancang pada penelitian ini yakni biobriket seperti pada Gambar 1. Hal ini dikarenakan material penyusun briket ini yakni dari material-material alam, seperti tempurung kepala, dan sekam padi.

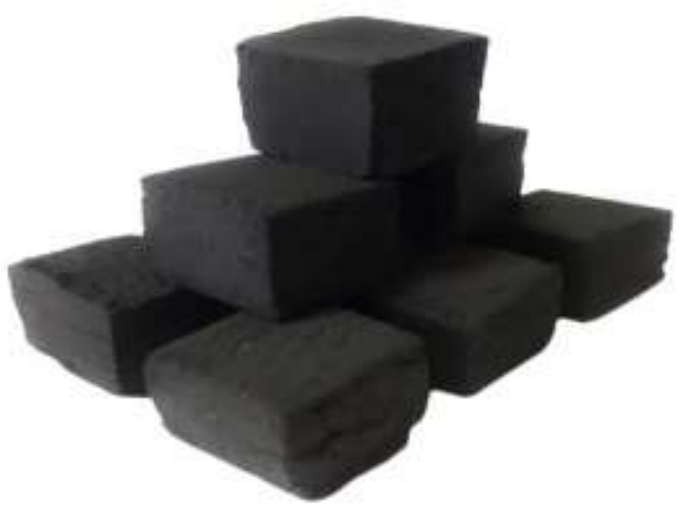

Gambar 1. Briket kubus 
Biobriket adalah bahan bakar yang potensial dan dapat diandalkan sebagai bahan bakar rumah tangga maupun industri. Kualitas biobriket yang dihasilkan menurut standar mutu Indonesia sebagaimana diperlihatkan pada tabel 2.

Tabel 2. Kualitas mutu biobriket arang.

\begin{tabular}{|c|c|}
\hline Karakteristik & Standar Mutu Briket SNI \\
\hline Kadar Air (\%) & Maks 8 \\
\hline Kadar Abu (\%) & Maks 8 \\
\hline Kerapatan $\left(\mathrm{gr} / \mathrm{cm}^{3}\right)$ & $0,5-0,6$ \\
\hline Kuat Tekan $\left(\mathrm{kg} / \mathrm{cm}^{2}\right)$ & Min 50 \\
\hline Nilai Kalor $(\mathrm{Kal} / \mathrm{gr})$ & Min 5000 \\
\hline
\end{tabular}

Nilai kalor dari biobriket lebih rendah daripada batu bara karena mempunyai kadar sulfur yang rendah yakni kuran dari $1 \%$

\section{METODE PENELITIAN}

\section{Preparasi Sampel}

Sampel yang digunakan pada penelitian ini yakni, tempurung kelapa, tongkol jagung, dan sekam padi. Sampel-sampel tersebut dikeringkan selama 12 jam dengan menggunakan cahaya matahari.

\section{Proses Karbonisasi}

Proses karbonisasi dilakukan dengan dua kali proses pengarangan, yaitu:

1. Menggunakan drum pengarangan, pembakaran dilakukan selama 5 jam untuk tempurung kelapa, 3 jam untuk tongkol jagung, dan 1 jam untuk sekam padi. Proses ini dilakukan bertujuan membuat sampel menjadi arang, dimana suhu yang digunakan sebesar $300^{\circ} \mathrm{C}-500^{\circ} \mathrm{C}$.

2. Menggunakan furnace, proses pada tahap ini bertujuan untuk mengontrol suhu pada proses menghasilkan arang. Selain itu, proses ini bertujuan untuk mendapatkan model sampel arang yang optimum.

\section{Menghaluskan dan mengayak sampel}

Alat yang digunakan pada tahapan ini yakni mortal, dimana fungsi dari mortal ini digunakan untuk menghaluskan sampel. Selain itu disaring, Sieve Shaker digunakan untuk menhasilkan sampel dengan ukuran 40 mesh. 


\section{Menghasilkan Sampel}

Massa bahan baku yang digunakan pada penelitian ini sebesar 30 gram dengan perekat sebanyak $10 \%$ dari massa bahan baku atau sebesar 3 gram, dan 20 $\mathrm{mL}$ air. Setelah itu, bahan baku tersebut dicampur dan diaduk hingga sampai menjadi homogen. Bahan baku yang sudah homogeny tersebut dimasukan kedalam cetakan berbentuk persegi panjang dengan ukuran $6 \mathrm{~cm} \times 5 \mathrm{~cm}$, dan $2 \mathrm{~cm}$. Setelah itu, proses pemadatan sampel tersebut dilakukan dengan dengan alat press manual. Sampel yang dihasilkan atau briket dikeringkan dengan menggunakan oven sharp pada suhu $110^{\circ} \mathrm{C}$ selama 24 jam.

\section{Uji Kualitas Sampel}

Kualitas sampel briket yang dihasilkan diuji dengan beberapa uji kualitas, seperti uji kuat tekan, kadar air, kadar abu, nilai kalor, dan lama pembakaran.

\section{HASIL DAN PEMBAHASAN}

Hasil yang diperoleh pada dari penelitian ini dapat dilihat pada tabel 3.

Tabel 3. Hasil pengujian sampel briket

\begin{tabular}{|c|c|c|c|c|c|c|}
\hline \multirow{3}{*}{$\begin{array}{l}\text { Ukuran } \\
\text { Partikel }\end{array}$} & \multirow{3}{*}{$\begin{array}{l}\text { Kode } \\
\text { Sampel }\end{array}$} & \multicolumn{5}{|c|}{ Nilai Hasil Pengujian } \\
\hline & & \multirow{2}{*}{$\begin{array}{c}\text { Kuat tekan } \\
\left(\mathrm{kg} / \mathrm{cm}^{2}\right)\end{array}$} & \multicolumn{2}{|c|}{ Kadar (\%) } & \multirow{2}{*}{$\begin{array}{c}\text { Nilai kalor } \\
\text { (kal/gr) }\end{array}$} & \multirow{2}{*}{$\begin{array}{c}\text { Lama } \\
\text { pembakaran } \\
\text { (menit) }\end{array}$} \\
\hline & & & Air & Abu & & \\
\hline \multirow{4}{*}{40 mesh } & $\mathrm{A}$ & 7.65 & 5.19 & 5.91 & 5117.67 & 128.18 \\
\hline & $B$ & 9.57 & 5.41 & 6.30 & 5594.36 & 115.34 \\
\hline & C & 8.81 & 4.59 & 4.69 & 5867.26 & 152.18 \\
\hline & $\mathrm{D}$ & 9.82 & 4.67 & 3.23 & 5888.55 & 145.17 \\
\hline
\end{tabular}

Rasio yang digunakan pada sampel A adalah 18:6:6, sampel B adalah 18:7.5:4.5, Sampel C adalah 18:9:3, dan sampel D adalah 18:10.5:1.5. Kuat Tekan yang dihasilkan dari sampel pada Tabel 1 ditunjukan pada Gambar 1. 


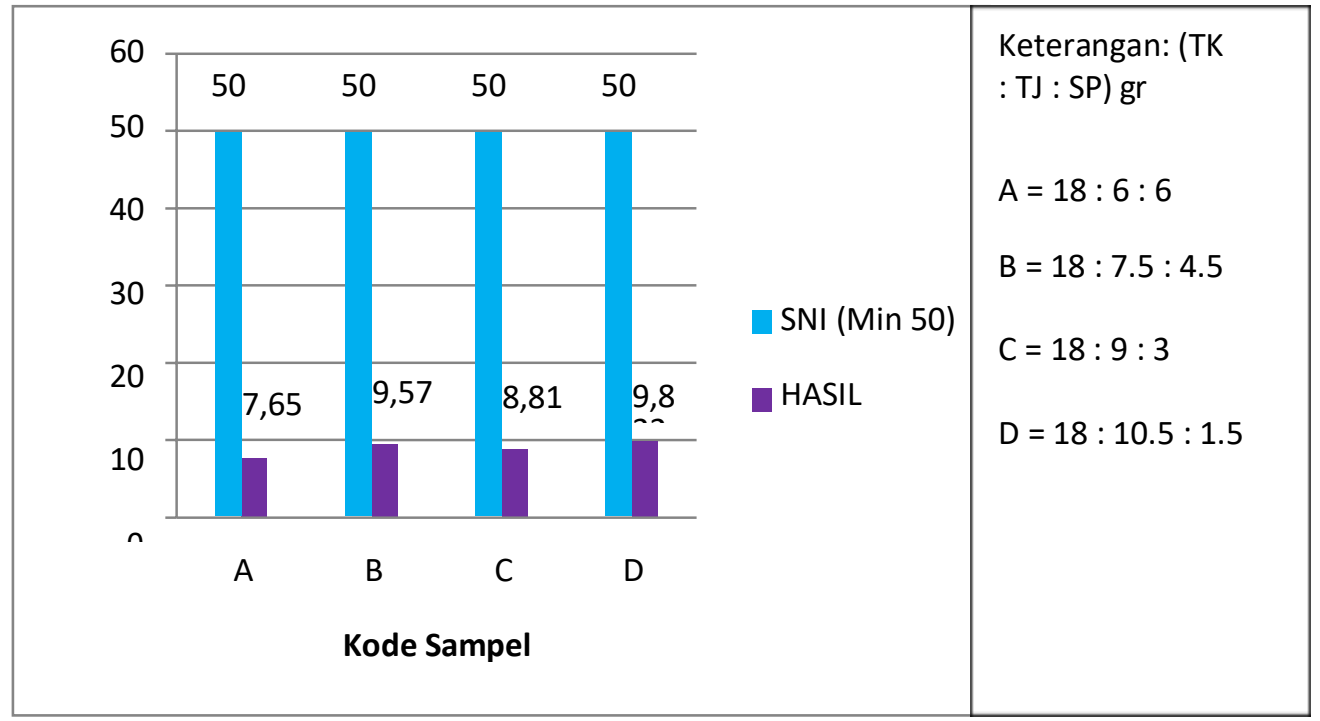

Gambar 2. Perbandingan biobriket SNI dengan hasil pengujian kuat tekan

Uji kuat tekan pada semua komposisi biobriket dengan campuran tempurung kelapa, tongkol jagung, dan sekam padi tidak ada yang memenuhi standar mutu biobriket sebesar minimal $50 \mathrm{~kg} / \mathrm{cm}^{3}$. Hal ini disebabkan pada saat proses pembuatan sampel menghasilkan campuran tidak homogen. Selain itu, tekanan yang yang dilakukan tidak tersandarisasi sehingga tekanan yang diberikan tidak menghasilkan gaya yang konstan. Hal ini dapat menghasil sampel biobriket yang berongga atau tidak termampatkan. Selain pengujian kuat tekan, Uji kadar air juga dilakukan pada penelitian ini.

Kadar air biobriket dapat dipengaruhi oleh jenis bahan baku, jenis perekat, dan metode pembuatan yang digunakan. Pada umumnya kadar air yang tinggi akan menurunkan nilai kalor dan laju pembakaran. Hal ini dikarenakan panas yang diberikan digunakan terlebih dahulu untuk menguapkan air yang terdapat di dalam biobriket. Biobriket memiliki tingkat kadar air yang tinggi, sehingga memiliki daya tahan yang tidak lama, dan mudah hancur. Penambahan perekat yang semakin tinggi menyebabkan air yang terkandung dalam perekat akan masuk dan terikat dalam pori arang. Selain itu, penambahan tersebut dapat berpengaruh terhadap nilai kalor yang dihasilkan. Oleh Karena itu, kadar air merupakan salah satu parameter dalam menentukan kualitas biobriket yang dihasilkan sebagaimana terlihat pada Gambar 3. 


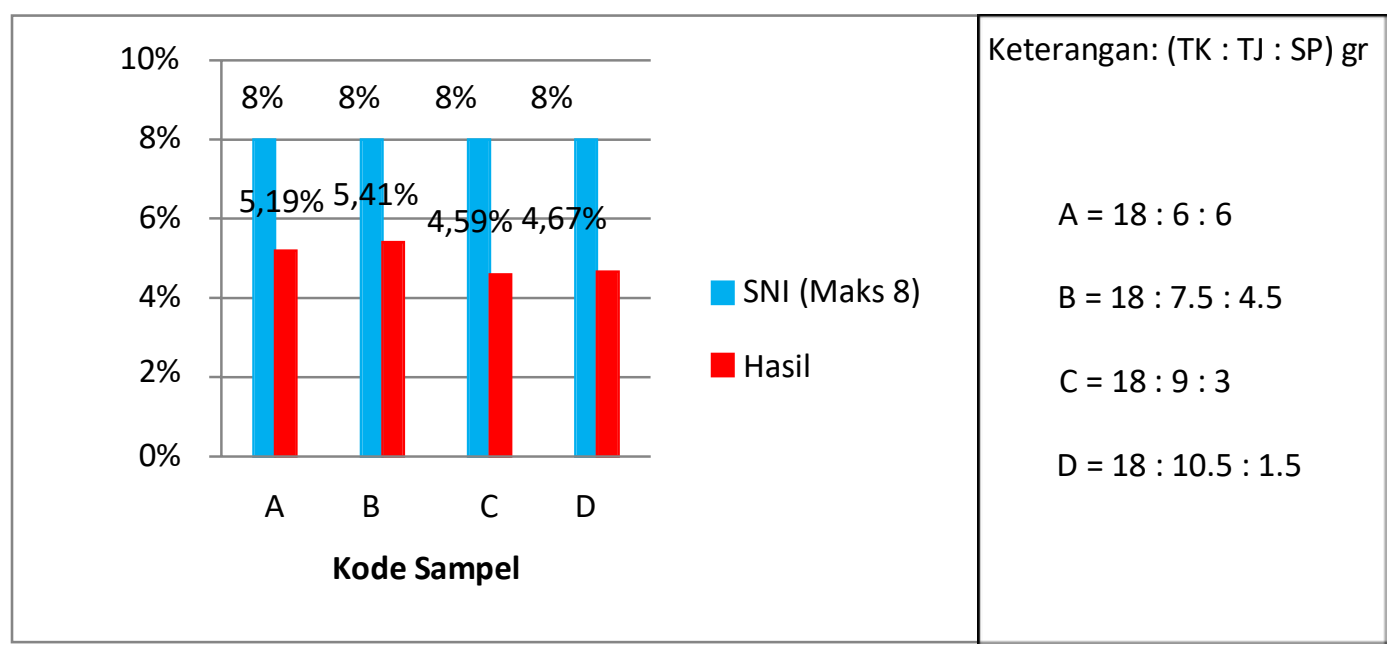

Gambar 3. Perbandingan biobriket SNI dengan hasil pengujian kadar air

Gambar 3 memperlihatkan perbandingan sampel biobriket yang dirancang dengan biobriket yang sesuai denga standar SNI, dimana hasilnya kadar air terendah, sebesar $4,59 \%$, berada pada sampel C dengan komposisi TK:TJ:SP yaitu 18:9:3, dan nilai tertinggi, sebesar $5,41 \%$, pada sampel B dengan komposisi TK:TJ:SP yaitu 18:7.5:4.5. Pengujian selanjutnya adalah pengujian kadar abu.

Nilai kadar abu dari biobriket yang dihasilkan ini telah memenuhi kualitas standar dari Jepang (3-6)\%, Inggris (5.9\%), Amerika (8.3\%) dan SNI 8\%. Nilai kadar abu terendah sebesar $3.23 \%$ terdapat pada kode sampel D dengan komposisi $18 \mathrm{gr}$ tempurung kelapa, $10.5 \mathrm{gr}$ tongkol jagung dan $1.5 \mathrm{gr}$ sekam padi sedangkan niai tertinggi yaitu $6.30 \%$ terdapat pada kode sampel B dengan komposisi $18 \mathrm{gr}$ tempurung kelapa, $7.5 \mathrm{gr}$ tongkol jagung dan 4.5 sekam padi. Dari data yang didapatkan menunjukkan semakin kecil komposisi sekam padi dalam campuran maka semakin rendah nilai kadar abu. Hal ini menunjukkan bahwa faktor jenis bahan baku yang dicampurkan berpengaruh nyata terhadap kadar abu yang dihasilkan. 


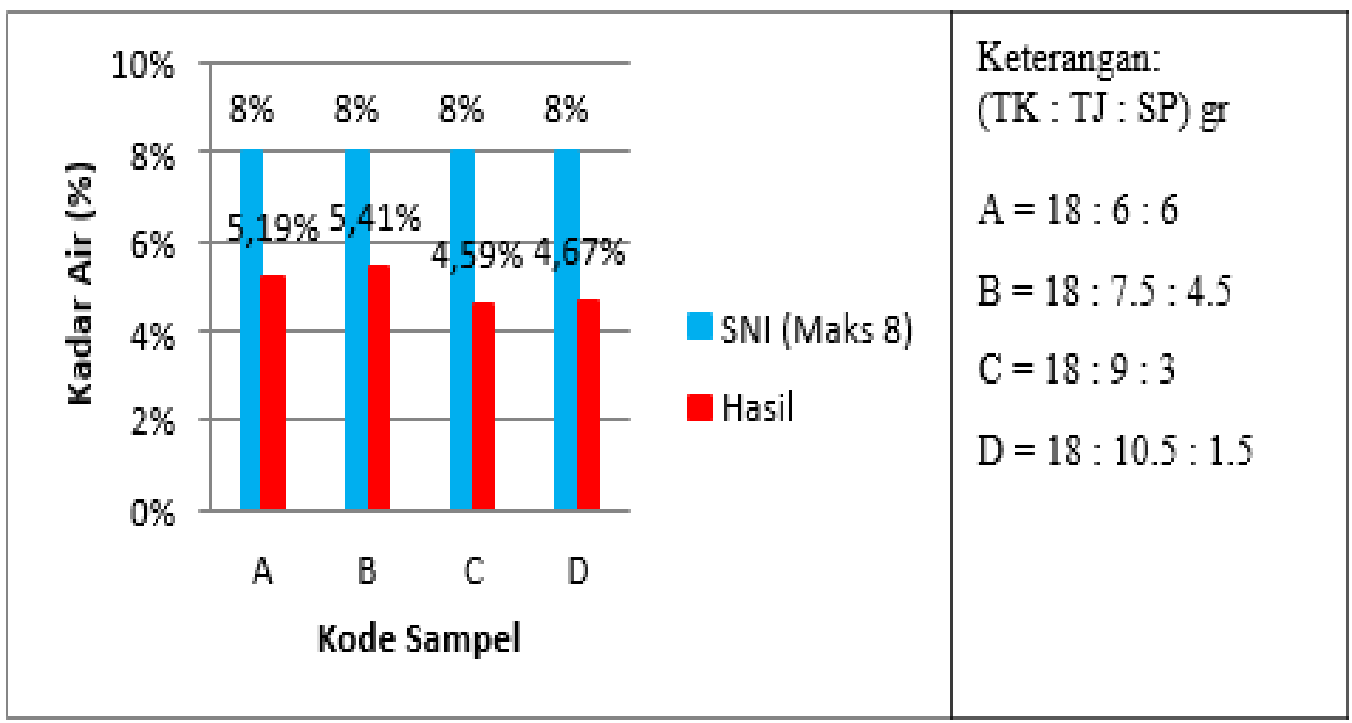

Gambar 4. Perbandingan biobriket SNI dengan hasil pengujian kadar abu.

Pengujian terakhir yang dilakukan pada penelitian ini yakni pengujian nilai kalor. Nilai kalor sangat menentukan kualitas/mutu biobriket. semakin tinggi nilai kalor yang dihasilkan, semakin baik kualitas biobriket itu. Nilai kalor yang didapatkan dari biobriket campuran tempurung kelapa, tongkol jagung dan sekam padi dengan beberapa komposisi dapat dilihat pada Gambar 5.

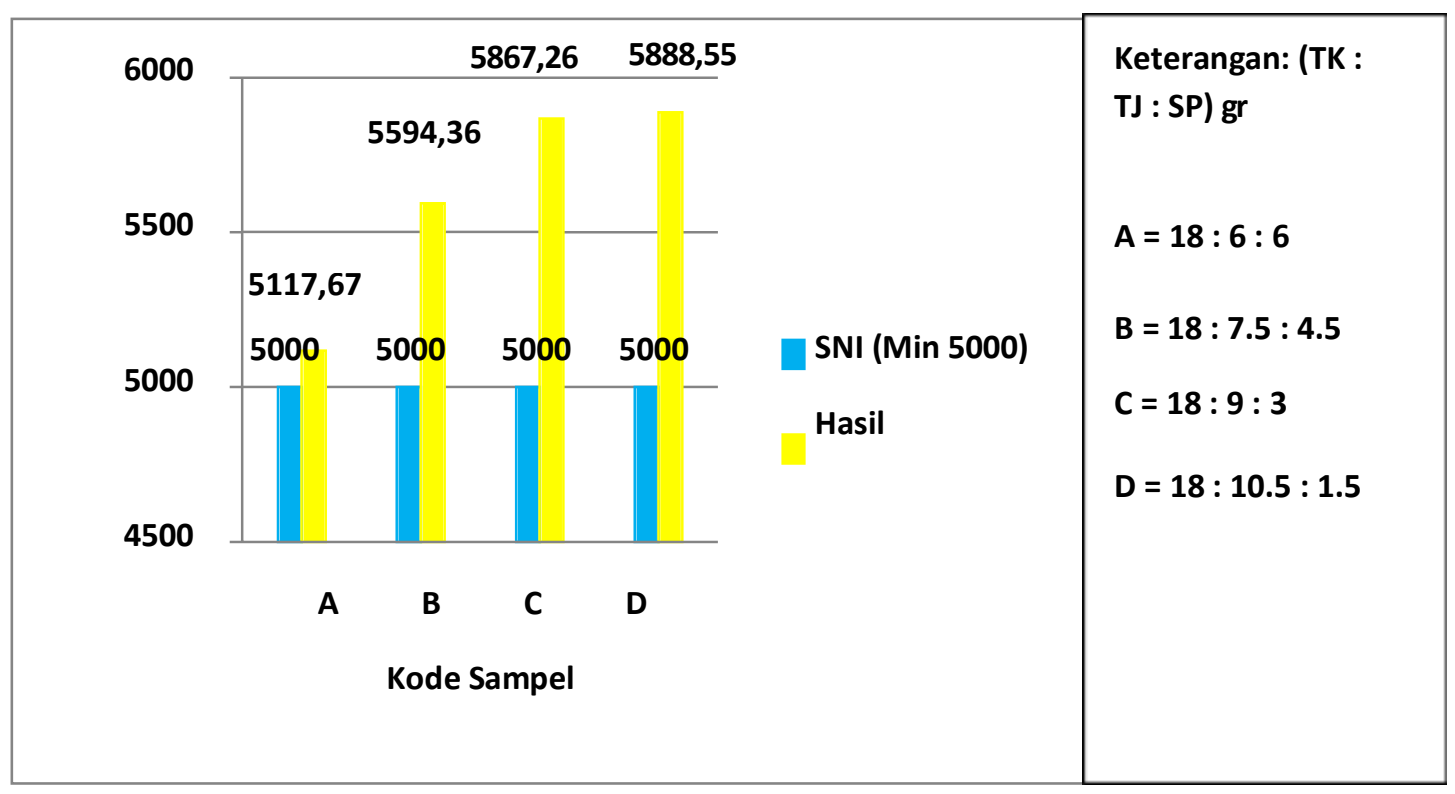

Gambar 5. Perbandingan biobriket SNI dengan hasil pengujian 
Berdasarkan gambar 5 disimpulkan nilai kalor yang tertinggi terdapat pada sampel D yaitu $5888.55 \mathrm{kal} / \mathrm{gr}$ dimana penyusun dari biobriket tersebut adalah $18 \mathrm{gr}$ TK: $10.5 \mathrm{gr}$ TJ: $1.5 \mathrm{gr}$ SP, dan terendah adalah pada sampel A yaitu $5117.67 \mathrm{kal} / \mathrm{gr}$ dengan komposisi $18 \mathrm{gr}$ TK: $6 \mathrm{gr}$ TJ: 6 gr SP. Oleh karena itu, komposisi tempurung kelapa ditetapkan konstan, sehingga variasi komposisi tongkol jagung dan sekam padi mempunyai konstribusi yang lebih besar dalam menghasilkan kalor. Gambar 5 juga memperlihatkan semakin besar komposisi tongkol jagung dalam campuran sampel maka akan memberikan nilai kalor yang besar pula, dan sebaliknya. Hasil pengujian nilai kalor didapatkan semua nilai telah memenuhi standar mutu biobriket Indonesia sebasar $5000 \mathrm{kal} / \mathrm{gram}$. Pengujian terakhir yang dilakukan pada penelitian ini yakni lama pembakaran dimana diperlihatkan pada gambar 6 .

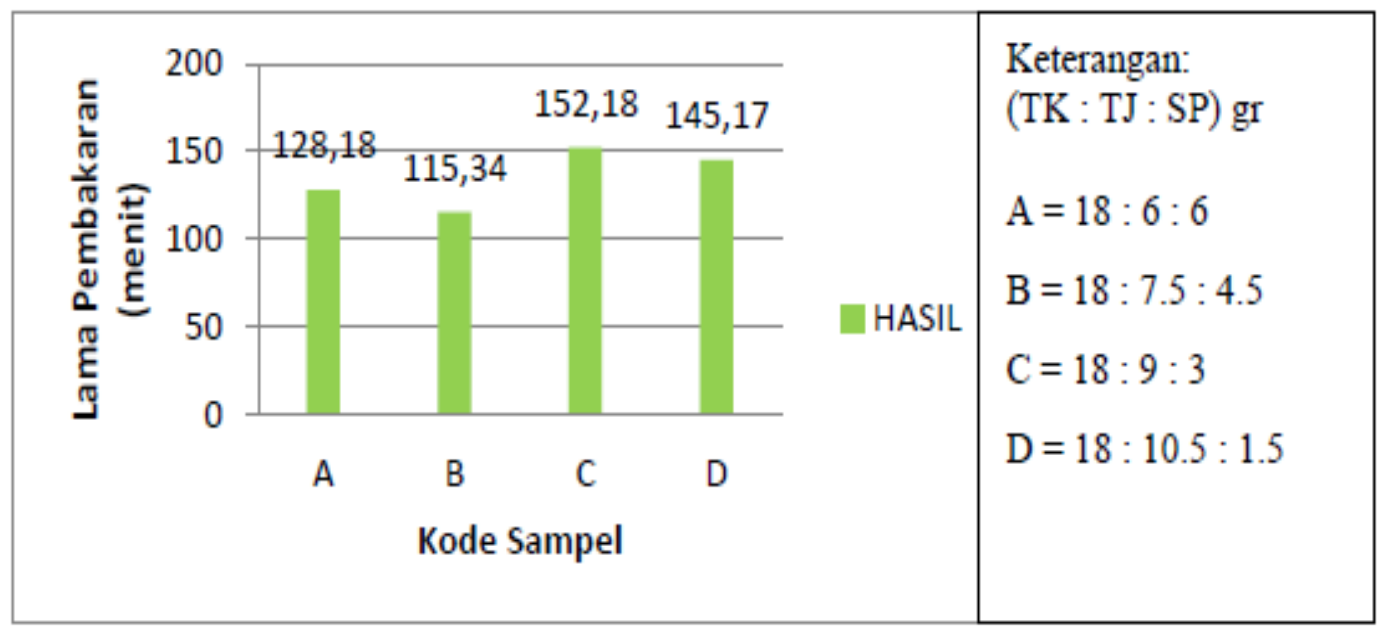

Gambar 6. Pengujian lama pembakaran.

Lama pembakaran adalah kemampuan biobriket yang dinyatakan dalam selang waktu dinyalakan pertama kali hingga mengalami proses pembakaran sempurna menjadi abu. Metode pengujian ini dilakukan dengan menggunakan stopwatch untuk menghitung waktu yang dibutuhkan biobriket dari nyala hingga menjadi abu. Gambar 6 menunjukan waktu yang paling lama adalah 152.18 menit pada sampel $\mathrm{C}$ dan yang cepat berubah menjadi abu memerlukan waktu sebesar 115.34 menit dengan kode sampel B sedangkan yang lain adalah adalah 128.18 menit untuk kode sampel A dan 145.17 menit untuk kode sampel D. jika dirataratakan hanya membutuhkan 12 buah briket untuk dapat menyala atau digunakan dalam waktu 24 jam

\section{KESIMPULAN}

Untuk mengetahui karakteristik material biobriket, penelitian ini dilakukan beberapa pengujian seperti uji kuat tekan, uji kadar air, uji kadar abu, uji nilai kalor, dan uji lama pembakaran. Berdasarkan uji tersebut disimpulkan bahwa kualitas 
biobriket yang dihasilkan dari campuran tempurung kelapa, tongkol jagung, dan sekam padi dapat dikategorikan baik. Hal ini dinyatakan karena sampel-sampel tersebut telah memenuhi standar SNI, kecuali pada pengujian kuat tekan yang tidak memenuhi standar SNI. Selain itu, pembakaran paling lama yakni 152 menit.

\section{DAFTAR PUSTAKA}

Adan, 1998, Membuat Briket Bio Arang. Yogyakarta : Kanisius.

Brades, A.C dan Tobing, F.S., 2007, Pembuatan Briket Arang Dari Enceng Gondok (Eichornia Crasipess Solm) Dengan Sagu Sebagai Pengikat. Jurusan Teknik kimia UNSRI: Inderalaya.

Mubarok, Rizal, M., dan Susila, I.W.,. 2015. Pengaruh Variasi Perekat Tetes Tebu Terhadap Karakteristik Briket Bioarang dari Limbah gergaji Kayu Mahoni. JTM Vol. 4, No. 1 (1-7). Universitas Negeri Surabaya: Surabaya.

Mutmainnah. 2012. Pemanfaatan Tongkol Jagung Sebagai Adsorben. JKK, 3(3): 713.

Permatasaari, Yudita, I., dan Utami, B., 2015. Pembuatan dan Karakteristik Briket Arang dari Limbah Tempurung Kemiri (Aleurites Moliccana) dengan Menggunakan Variasi Jenis Bahan Perekat dan Jumlah Bahan Perekat. Hal. 59-69. Universitas Sebelas Maret Yogyakarta:Yogyakarta.

Nurdin, Hendri. dkk, 2018. Karakteristik Nilai Kalor Briket Tebu Tibaran Sebagai Bahan Bakar Alternatif. Universitas Negeri Padang: Padang. INVOTEK (Jurnal Inovasi Vokasional dan Tekhnologi), Vol (18) No. 1: 18-24. 